\title{
Proposal of public policies regarding the introduction of first aid courses for emergency situations in schools
}

\author{
Sava (Mihalcea) Mirela Camelia \\ Cucuteanu (Gurei) Rodica Valentina \\ Pușa (Grosu) Mariana Camelia \\ Master of Management of public institutions (Faculty of Law and Administrative Sciences - \\ "Ovidius" University of Constanta, Romania) \\ rodica.gurei@yahoo.com
}

\section{Volume coordinators}

Prof. univ. dr. habil. Mihaela Rus

"Ovidius" University of Constanta (Faculty of Law and Administrative Sciences)

psiholog_m@yahoo.com

\section{Lect. univ. dr. Mihaela Sandu}

"Ovidius" University of Constanta (Faculty of Psychology and Educational Sciences)

mihaela_naidin@yahoo.com

\author{
Asist. univ. dr. Tănase Tasențe \\ "Ovidius" University of Constanta (Faculty of Law and Administrative Sciences) \\ office@pluscommunication.eu
}

\begin{abstract}
Situations such as the fire from the "Colectiv" club, the floods and the last great earthquakes, have shown that the population of Romania is not prepared for such situations and the efforts made so far have not proved their efficiency. In these situations, it is proven that the number of victims could be smaller if those present knew how to rationally manage the situation. The objective of the public policy proposal is to integrate first aid courses in emergency situations in schools.
\end{abstract}

Keywords. public policy, first aid courses, emergency situations, schools, Romania 


\begin{tabular}{|c|c|}
\hline $\begin{array}{l}\text { The institution } \\
\text { that initiates } \\
\text { public policy }\end{array}$ & $\begin{array}{c}\text { Ministry of National Education, Ministry of Youth and Sport } \\
\text { Ministry of Health } \\
\text { General Inspectorate for Emergency Situations } \\
\text { Red Cross }\end{array}$ \\
\hline $\begin{array}{l}\text { The nature of the } \\
\text { problem }\end{array}$ & $\begin{array}{l}\text { Situations such as the fire from the "Colectiv" club, the floods and the last } \\
\text { great earthquakes, have shown that the population of Romania is not } \\
\text { prepared for such situations and the efforts made so far have not proved } \\
\text { their efficiency. } \\
\text { Studying the history of earthquakes in Romania, we observe a periodicity } \\
\text { with which they occur with high magnitude, which causes material } \\
\text { damage and losses of human lives. The winter season, as well as the } \\
\text { melting period of the snow that leads to floods, surprise the authorities } \\
\text { prepared insufficiently. } \\
\text { The problem identified has several dimensions, namely: } \\
\text { - lack of a properly formulated curriculum, which contains complex } \\
\text { topics: the topics are superficially addressed, discussed in general } \\
\text { and only once per semester about fire and earthquakes. } \\
\text { - lack of training of teachers in the field of emergency situations, } \\
\text { usually teach teachers without specific knowledge } \\
\text { - students do not have first aid hours, except for those who } \\
\text { participate in specific competitions } \\
\text { the fact that information on emergency situations is occasionally } \\
\text { presented } \\
\text { poor information from parents about the importance of these } \\
\text { courses }\end{array}$ \\
\hline $\begin{array}{l}\text { Name of the } \\
\text { policy }\end{array}$ & $\begin{array}{l}\text { Proposal of public policies regarding the introduction of first aid courses } \\
\text { for emergency situations in schools }\end{array}$ \\
\hline Purpose & $\begin{array}{l}\text { The intention of the initiating institutions is that through this educational } \\
\text { policy the focus will be on the formation of an educated citizen, well } \\
\text { informed from all points of view, who has minimal knowledge about the } \\
\text { rules necessary for his active participation in case of natural disasters, } \\
\text { accidents, fires but also other types of situations at risk that require first } \\
\text { aid knowledge. } \\
\text { Therefore, the aim is to implement a national program aimed at educating } \\
\text { students, the ultimate goal being to raise awareness of its impact and } \\
\text { importance in training them as individuals, but also to adapt to situations } \\
\text { that require basic knowledge of personal protection as well as help offered } \\
\text { to others. }\end{array}$ \\
\hline $\begin{array}{c}\text { General } \\
\text { objective / } \\
\text { Specific } \\
\text { objectives }\end{array}$ & $\begin{array}{l}\text { General objective: Integration of first aid courses in emergency } \\
\text { situations in schools } \\
\text { Specific objectives: } \\
\text { 1. Teacher training - } 1 \text { year; } \\
\text { 2. Providing the teaching materials regarding the first aid, in relation to } \\
\text { the age and the implicit interests for the primary cycle, the gymnasium } \\
\text { cycle, high school respect - } 2 \text { years; }\end{array}$ \\
\hline
\end{tabular}




\begin{tabular}{|c|c|c|}
\hline & \multicolumn{2}{|c|}{$\begin{array}{l}\text { 3. Mandatory introduction of first aid hours in emergency situations in } \\
\text { schools and high schools - } 2 \text { years; } \\
\text { 4. Familiarization of young people with the importance of granting the } \\
\text { first aid maneuvers in the first minutes after the event has been produced } \\
\text { through popularization actions - } 1 \text { year; } \\
\text { 5. Stimulating the NGOs in order to establish partnerships with schools } \\
\text { and high schools in Romania for the creation of events and campaigns } \\
\text { with an informative role - } 2 \text { years; } \\
\text { 6. Encourage young people to have an open vision towards others and the } \\
\text { special situations that may occur and that they can become savior for } \\
\text { others but also for themselves through information sessions - } 1 \text { year; } \\
\text { 7. Reducing the number of deaths in situations such as natural disasters, } \\
\text { accidents, fires and other types of situations at risk - } 10 \text { years; } \\
\text { 8. Encourage parents to discuss with children about aspects of education } \\
\text { regarding emergency situations and first aid - permanent term; }\end{array}$} \\
\hline Ben & $\begin{array}{l}\text { 1. Direct: the students } \\
\text { 2. Indirect: parents, teacher } \\
\text { structures; }\end{array}$ & s, doctors, psychologists, specialized \\
\hline $\begin{array}{l}\text { Solution } \\
\text { alternatives }\end{array}$ & $\begin{array}{l}\text { Solution alternatives no. 1 } \\
\text { The Ministry of National } \\
\text { Education, the Ministry of Youth } \\
\text { and Sport, the General } \\
\text { Inspectorate for Emergency } \\
\text { Situations, the Ministry of } \\
\text { Health propose to modify the } \\
\text { school syllabus and to introduce } \\
\text { an hour of first aid in weekly } \\
\text { emergency situations for } \\
\text { students of grades I - XII. To } \\
\text { focus on the practical part of the } \\
\text { problem and the risks of } \\
\text { neglecting this area at national } \\
\text { level. The government will make } \\
\text { the necessary steps to create an } \\
\text { interactive online platform that } \\
\text { will take the place of the classic } \\
\text { course manual, } \\
\text { presentations of concrete cases } \\
\text { and specific measures. Each } \\
\text { teacher will be trained in } \\
\text { providing first aid and managing } \\
\text { different emergency situations. } \\
\text { Information support will be } \\
\text { provided through brochures and } \\
\text { campaigns with various partner } \\
\text { NGOs, Red Cross, General }\end{array}$ & $\begin{array}{l}\text { Impact } 1 \\
\text { Proposing a modern way of } \\
\text { approaching the stated problem, we } \\
\text { will find a responsibility in this regard } \\
\text { for students and future generations; } \\
\text { young people will increase their self- } \\
\text { esteem, by accumulating new } \\
\text { knowledge and by the ability to help } \\
\text { and save human lives. } \\
\text { The applicability of these accumulated } \\
\text { knowledge will be useful regardless of } \\
\text { the subsequent school year. } \\
\text { The costs generated by this initiative } \\
\text { can be high but the general benefit of } \\
\text { the population will justify this } \\
\text { investment. } \\
\text { To carry out this proposal, the } \\
\text { procedures for attracting European } \\
\text { funds and the participation of NGOs } \\
\text { can be started. } \\
\text { or of companies with specific in this } \\
\text { field. }\end{array}$ \\
\hline
\end{tabular}




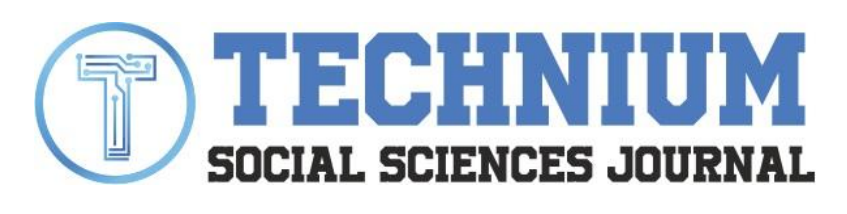

Technium Social Sciences Journal

Vol. 3 (2), 34-38, February 2020

ISSN: 2668-7798

www.techniumscience.com

\begin{tabular}{|c|c|c|}
\hline \multirow[t]{2}{*}{ 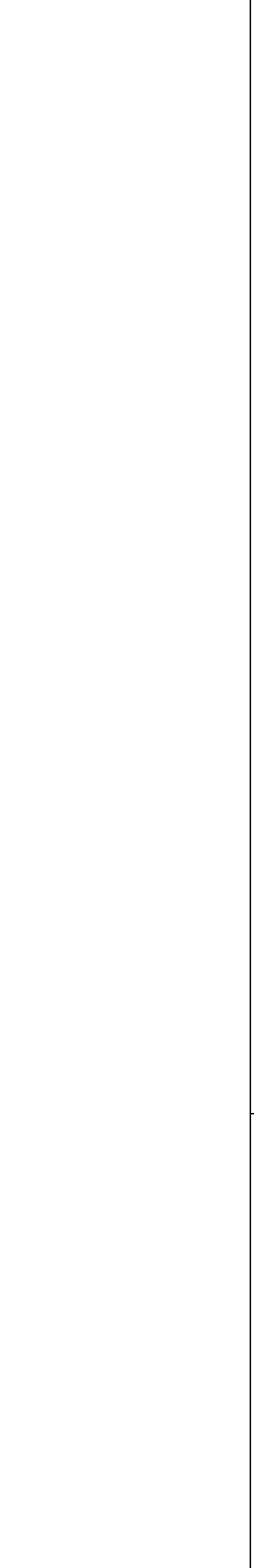 } & $\begin{array}{l}\text { Inspectorate for Emergency } \\
\text { Situations } \\
\text { Benefits: } \\
\text { - Students will have permanent } \\
\text { access to accredited information } \\
\text { in the field of first aid in } \\
\text { emergency situations; } \\
\text { - Offering an attractive study } \\
\text { alternative for young people who } \\
\text { are increasingly connected to } \\
\text { technology; } \\
\text { - The possibility } \\
\text { understanding the various topics } \\
\text { based on interactive audio-video } \\
\text { media, } \\
\text { - Formation of generations of } \\
\text { students prepared for special } \\
\text { situations. } \\
\text { - Decreased mortality due to } \\
\text { failure to provide first aid in } \\
\text { time, among the population, } \\
\text { effects that will be seen in time. } \\
\text { Risks: } \\
\text { The parents' intervention } \\
\text { regarding the increase of the } \\
\text { number of hours of the students } \\
\text { Logistics in educational } \\
\text { establishments projectors, } \\
\text { (computers, video } \\
\text { internet connection, etc.) }\end{array}$ & \\
\hline & $\begin{array}{l}\text { Solution alternatives no. } 2 \\
\text { Semi-annual organization of } \\
\text { information sessions on first aid } \\
\text { in emergency situations } \\
\text { Students will be able to receive } \\
\text { the necessary information, } \\
\text { leaflets, brochures. } \\
\text { Benefits: } \\
\text { - Informing students; } \\
\text { - Awareness of the problem and } \\
\text { the need to approach it with } \\
\text { special attention; }\end{array}$ & $\begin{array}{l}\text { Impact } 2 \\
\text { This variant would have a low impact } \\
\text { on students and young people, a } \\
\text { semester session being insufficient to } \\
\text { address all the topics in the field of } \\
\text { first aid and emergency situations. } \\
\text { The significantly lower costs } \\
\text { generated by this way of } \\
\text { implementing the program can also be } \\
\text { taken into account. }\end{array}$ \\
\hline
\end{tabular}




\begin{tabular}{|c|c|}
\hline & $\begin{array}{l}\text { Risks: } \\
\text { minimal attention to this area } \\
\text { from the students, } \\
\text { lack of demonstrations based on } \\
\text { those presented }\end{array}$ \\
\hline $\begin{array}{l}\text { The consultation } \\
\text { process }\end{array}$ & $\begin{array}{l}\text { In order to formulate this public policy and to identify the strategic points } \\
\text { for its definition, meetings were held, both with the qualified personnel } \\
\text { from the public administrations and with other important parts of this } \\
\text { project. They generated the information needed to formulate concrete } \\
\text { suggestions and recommendations in order to make a reliable public } \\
\text { policy proposal, which would be a real solution to this national problem. } \\
\text { Thus, the parties consulted were: } \\
\text { - Representatives of some institutions and organizations: Ministry of } \\
\text { National Education, Ministry of Youth and Sport, Ministry of Health, } \\
\text { General Inspectorate for Emergency Situations, Red Cross, Save the } \\
\text { Children, Doctors without Borders. } \\
\text { - Representatives of the students by age groups; } \\
\text { - Parents, teachers, doctors, members of the National Institute of } \\
\text { Statistics of Romania. }\end{array}$ \\
\hline $\begin{array}{l}\text { Recommended } \\
\text { solution }\end{array}$ & $\begin{array}{l}\text { Following the consultations, it was recommended that the optimal } \\
\text { solution solution, the number one variant. Although it involves high costs, } \\
\text { it is a direct investment in the formation of well-informed generations on } \\
\text { issues that concern the interests of each one, sooner or later. For this } \\
\text { variant, a strategy for creating and developing interactive programs by } \\
\text { 2022. could be prepared. The weekly presentation of the information as } \\
\text { well as their diversity can make the citizen responsible by providing the } \\
\text { desired answers. }\end{array}$ \\
\hline
\end{tabular}

